\title{
Basic Study on Term of Warranty Liability for Finish Work Defect in Apartment Building
}

\author{
Junmo Park and Deokseok Seo
}

\begin{abstract}
In Korea, disputes and lawsuits over the defect of apartment building are constantly becoming a social problem. In lawsuits over the defect the apartment building, the term of warranty liability, as the period that can demand the defect repair according to defect occurrence, is important because it is the exclusion period of the exercise of rights. However, at the time of enactment of the relevant law and regulation, it was described without sufficient basis, and subsequent amendments were made arbitrarily without clear basis. Therefore, it is necessary to formulate a basis system promptly through sufficient research and review related to the term of warranty liability. This study conducted basic research for a reasonable establishment of term of warranty liability for the subject of the finish work defect out of various defects occurring in the apartment building. We investigated the number of defect occurrence in 177 apartment complexes and reviewed the trends of defects by detailed construction type and by year. As a result, the total number of occurrences of defects was $1,449,745$, and the number one of defect occurrence was finishing work by $42.54 \%$. In addition, if detailed construction types of the finishing work are listed the in order from the largest number of occurrences of defects, it showed in order of indoor furniture work, tile work, wallpaper work, interior work, painting work, plastering work, insulation work. On the other hand, as a result of reviewing defect occurrence and accumulated trends every year from 1 to 10 years on the number of defect occurrence of finishing work by term of warranty liability, it was found that 6 construction types of finishing works except for insulation work had defects of more than $50 \%$ after the first year of completion. Also, in the third year of completion, the accumulated trends of defect occurrence exceeded $90 \%$ in all of 6 detailed construction types of works except for painting work. The overall tendency of defect occurrence trends showed that defect occurrence in 6 detailed construction type except for insulation work was concentrated in the 1 st to 2 nd year, that is, the number of defect occurrence of the 1 st year was very large, started to decrease rapidly from the 2 nd year, and was very small from the 3 rd year.
\end{abstract}

Index Terms-Term of Warranty Liability, Finish Work Defect, Defect Lawsuit, Apartment Building, Housing Law

\section{INTRODUCTION}

\section{A. Background}

In Korea, the dominant forms of housing are chiefly apartment houses, especially apartments (more than five stories). These apartments are very popular in Korea because they are more advantageous than existing houses in terms of convenience,

Manuscript received December 9, 2016.

Junmo Park, Gyeongsan Engineering, Seocho-gu, Seoul, 06646, Korea

Deokseok Seo, School of Architecture, Halla University, Wonju-si, Gangwon, 26404, Korea maintenance cost, safety, etc. Because of this, many Koreans are living in apartments or hoping to live in [1].

However, Korean apartments are expensive among housing, and the disputes surrounding them are accelerating due to the upgraded image by the subject of the business and the improvement of the divided owner's eye level.[2] The defect dispute over the apartment is expanding into lawsuit, which is pointed out as a big social problem. This is called a defect lawsuit, and it is a lawsuit in which a division owner claims damages to business subject on behalf of business subject who should be liable for defect repair.

The term of warranty liability for apartment housing is exclusion period of the exercise of rights as the period that can demand the defect repair according to defect occurrence. At the same time, it is a standard for preventive and smooth maintenance of apartment housing. This was stated in the Housing Act [3] and is one of the important legal issues and judging criteria in the case of defect dispute. In particular, it is very important because the right to request defect repair is judged under term of warranty liability and rejected if the liability period expires.

However, there was no ground for establishing at the time of enactment of law and regulation in this regard. Although it was arbitrarily stipulated in the first Decree on the Management of Apartment Houses [4], provisions were added, deleted, and the period changed as the law revision was done several times. In addition, recently the amendment of the Apartment Housing Management Act [5] has changed the term of warranty liability, but this has also been done arbitrarily without clear ground.

In order to overcome these limitations, we need sufficient research and review on the term of warranty liability, which is an important agenda of the defect dispute, and should establish the term of warranty liability based on this.

\section{B. Purpose}

In order to maintain the apartment housing smoothly and to resolve the dispute smoothly, the contradiction in term of warranty liability stipulated in the current laws and regulations be resolved. Therefore, the provisions of the legal system for the term of warranty liability should be revised according to the objective facts and the result of logical interpretation thereof. This study was conducted as part of the basic research for establishing such a reasonable term of warranty liability.

\section{Scope and Method}

This study investigated the finish work defect of among various defects occurring in apartment housing. Finishing works 
are the most defects in the number of defect occurrence, and they are also important in terms of defect repair cost.

For this study, we investigated the number of defects occurring in apartment housing in Korea. In addition, we examined the occurrence trends of defects occurring in 18 construction types under the Housing Act [3] from 1 year to 10 years by term of warranty liability.

\section{LITERATURE REVIEW}

\section{A. Finish Work Defect}

Among the defects occurring in finish work of apartment housing, the followings are typical, and the types are much more varied (Table I). Also, finish work is the second most important construction type in terms of defect repair cost [6].

TABLE I: DETAILED TYPE OF FINISH WORK DEFECT

\begin{tabular}{|c|c|c|c|}
\hline No & Detailed Type & No & Detailed Type \\
\hline 1 & Poor drainage & 12 & Bad floor tile \\
\hline 2 & Poor plastering finish & 13 & Wall damage \\
\hline 3 & $\begin{array}{l}\text { Poor penetration finish } \\
\text { construction }\end{array}$ & 14 & Bathroom threshold low \\
\hline 4 & $\begin{array}{l}\text { Poor filling up around window } \\
\text { frame }\end{array}$ & 15 & Tile joint crack and breakage \\
\hline 5 & $\begin{array}{l}\text { Floor expansion joint } \\
\text { unfinished construction and } \\
\text { alteration construction }\end{array}$ & 16 & Braille Block Missing \\
\hline 6 & $\begin{array}{l}\text { Ondol floor discoloration, } \\
\text { lifting, and breakage }\end{array}$ & 17 & Moisture buildup \\
\hline 7 & Poor boarding and Lifting & 18 & $\begin{array}{l}\text { Distorted furniture and poor } \\
\text { opening/closing }\end{array}$ \\
\hline 8 & $\begin{array}{l}\text { Kitchen sink bottom and rear } \\
\text { wall finish Unfinished } \\
\text { construction }\end{array}$ & 19 & Poor sink top \\
\hline 9 & Paint peeling off & 20 & Poor Kitchen furniture \\
\hline 10 & $\begin{array}{l}\text { Duster baseboard paint } \\
\text { unfinished construction }\end{array}$ & 21 & $\begin{array}{l}\text { Poor Kitchen installation } \\
\text { Electronic equipment }\end{array}$ \\
\hline 11 & Wallpaper damage & & \\
\hline
\end{tabular}

Finish work is likely to be subject to dispute because it is easily visible to the resident of apartment building. For example, in the case of painting work, it is natural that there is a change in the paint surface due to discoloration and contamination over time. Therefore, it is prescribed by law to observe and repair it periodically. However, this is often misunderstood or over-interpreted to claim cracking or corrosion of reinforced concrete surfaces, which is the subject of dispute. The finish work defects are mainly related to beauty and not related to safety, but they are relatively relevant in terms of functionality.

\section{B. Definition on Term of Warranty Liability}

The definition of term of warranty liability is described in the Housing Act. In addition, the term of warranty liability is set for each by 80 detailed construction type belonging to 18 major construction type (Table II).
TABLE II : TERM OF WARRANTY LIABILITY ON APARTMENT BUILDING WORK

\begin{tabular}{|c|c|c|}
\hline Code & Apartment Building Work & Type of Detailed Work \\
\hline 1 & Site Work & 5 \\
\hline 2 & $\begin{array}{l}\text { Outdoor Water Supply and Sanitation } \\
\text { Facility Work }\end{array}$ & 4 \\
\hline 3 & Footing and Foundation Work & 2 \\
\hline 4 & Reinforced Concrete Work & 3 \\
\hline 5 & Steel Work & 3 \\
\hline 6 & Brick Work & 3 \\
\hline 7 & Wood Work & 2 \\
\hline 8 & Window and Door Work & 3 \\
\hline 9 & Roofing and Waterproofing Work & 3 \\
\hline 10 & Finish Work & 7 \\
\hline 11 & Landscape Work & 6 \\
\hline 12 & Miscellaneous Work & 4 \\
\hline 13 & $\begin{array}{l}\text { Heating, Ventilation, and Air } \\
\text { Conditional Facility Work }\end{array}$ & 6 \\
\hline 14 & $\begin{array}{l}\text { Water Supply, Drainage, and } \\
\text { Sanitation Arrangement Work }\end{array}$ & 6 \\
\hline 15 & Gas and Fire Extinguish Facility Work & 4 \\
\hline 16 & $\begin{array}{l}\text { Electricity and Electric Power Facility } \\
\text { Work }\end{array}$ & 9 \\
\hline 17 & $\begin{array}{l}\text { Telecommunication, Signal, and } \\
\text { Emergency Equipment Work }\end{array}$ & 7 \\
\hline 18 & $\begin{array}{l}\text { Intelligence Home Network } \\
\text { Equipment Work }\end{array}$ & 3 \\
\hline & Sum & 80 \\
\hline
\end{tabular}

On the other hand, finish work in accordance with standard of the Housing Act consists of seven detailed construction types such as plastering work, interior finishing work, painting work, wallpaper work, tile work, insulation work, indoor furniture work, and each term of warranty liability is shown in the following table (Table III).

TABLE III: TERM OF WARRANTY LIABILITY IN HOUSING LAW

\begin{tabular}{llll}
\hline \hline \multirow{2}{*}{ Code } & \multirow{2}{*}{ Detailed Work } & \multicolumn{2}{l}{ Term of Warranty Liability } \\
\cline { 3 - 4 } & & 1 year & 2 year \\
\hline 10.1 & Plastering Work & $\bullet$ & \\
10.2 & Interior Finishing Work & $\bullet$ & \\
10.3 & Painting Work & $\bullet$ & $\bullet$ \\
10.4 & Wallpaper Work & $\bullet$ & $\bullet$ \\
10.5 & Tile Work & & $\bullet$ \\
10.6 & Insulation Work & & \\
10.7 & Indoor Furniture Work & & \\
\hline \hline
\end{tabular}

\section{History of Law Revision}

The term of warranty liability is divided into structural parts such as pillars, beams, floors, walls, etc. which are the main structures supporting the structural strength. On the other hand, other parts such as windows, paintings, etc. can be divided into other parts or construction types. The related law and regulation described the term of warranty liability have changed as follows (Table IV). The Regulations on the Management of Apartment Buildings [7], which was first enacted in 1979, had no provision for the structural strength, and described one or two years of term of warranty liability by each construction type. Then, in 1981, Decree on the Management of Apartment Houses [4] was enacted, and for the first time, five years or ten years of term of warranty liability for the structural strength was established. As Decree on the Management of Apartment Houses was revised in 1998 , the terms of warranty liability were changed to $1,2,3$ years. In 2003, the related regulations were transferred to 
Enforcement Decree of the Housing Act, then transferred to Housing Act [3] in 2005, and then transferred to the Enforcement Decree of the Housing Act in 2007, the terms of warranty liability for other construction types were changed to 1, 2, 3, 4 years. Recently, in 2016, with the revision to the Apartment House Management Act [5], the terms of warranty liability by major construction type were greatly changed.

TABLE IV: HISTORY OF LAW REVISION

\begin{tabular}{|c|c|c|c|}
\hline \multirow[b]{2}{*}{ Date } & \multirow[b]{2}{*}{ Law and Regulation } & \multicolumn{2}{|c|}{ Term of Warranty Liability } \\
\hline & & $\begin{array}{l}\text { Load bearing } \\
\text { Part in Structure }\end{array}$ & Others \\
\hline 1979 & $\begin{array}{l}\text { Regulations } \text { on the } \\
\text { Management of Apartment } \\
\text { Buildings }\end{array}$ & - & 1,2 years \\
\hline 1981 & $\begin{array}{l}\text { Decree on the Management of } \\
\text { Apartment Houses }\end{array}$ & 5,10 years & 1,2 years \\
\hline 1998 & $\begin{array}{l}\text { Decree on the Management of } \\
\text { Apartment Houses }\end{array}$ & 5,10 years & $1,2,3$ years \\
\hline 2003 & $\begin{array}{l}\text { Enforcement Decree of the } \\
\text { Housing Act }\end{array}$ & 5,10 years & $1,2,3$ years \\
\hline 2005 & Housing Law & 5,10 years & $1,2,3$ years \\
\hline 2007 & Housing Law & 5,10 years & $1,2,3,4$ years \\
\hline 2016 & $\begin{array}{l}\text { Apartment } \\
\text { Management Law }\end{array}$ & 5,10 years & 2,3 years \\
\hline
\end{tabular}

\section{Problem of Current Law and Regulation}

As a result of reviewing the history of the laws and regulations related to the above-mentioned term of warranty liability, there were no specified grounds or reasons for establishing the term of warranty liability anywhere.

It is considered to be a big problem that even though the term of warranty liability, which was important criteria of defect dispute, was arbitrarily enacted, the clause was added or deleted several times, and the term was changed, there was no reason to support it.

\section{REVIEW ON OCCURRENCE OF DEFECT}

\section{A. Outline}

As previously discussed, it was confirmed that there was no ground for establishing the term of warranty liability in the laws and regulations related to apartment housing. Therefore, in this study, we examined an alternative to improve it. We investigated the actual status of defects in apartment housing, and tried to grasp to what extent defects occur, and at which time defects are concentrated

This study surveyed the number of defects that occurred in 177 apartment complexes constructed by 12 comprehensive construction companies in Korea. The subjects were completed from 2002 to 2011. The size of households varied from 54 households to 3,906 households, totaling 125,816 households. In addition, the area of each household varied and the number of stories was different. However, in this study, it is noted that only the defects were considered without consideration of these matters. In addition, the number of cases counted as a result of the survey was not the consideration of the construction amount, construction difficulty, etc., but the sum of the number of cases where pure defects occurred.

\section{B. Occurrence of Total Defect}

A total of $1,449,745$ cases were found in the apartment complex surveyed. The 1st place of the number of defects was finish work of $42.54 \%$, and the 2nd was outdoor water supply and sanitation facility work of $13.72 \%$. The 3 rd place was a window and door work by $12.66 \%$ of defects, and the 4 th place was wood work of $8.65 \%$. The 5 th place was miscellaneous work of $7.41 \%$, and the 6th place was electricity and electric power facility work of $7.20 \%$. The defect occurrence of other 12 construction types was very small compared to the 6 construction types above. When all the defects occurring from these types were combined, it was $7.82 \%$ (Figure 1).

Through this, it was confirmed that the most frequent construction type out of defects occurring in apartment housing was the finish work.

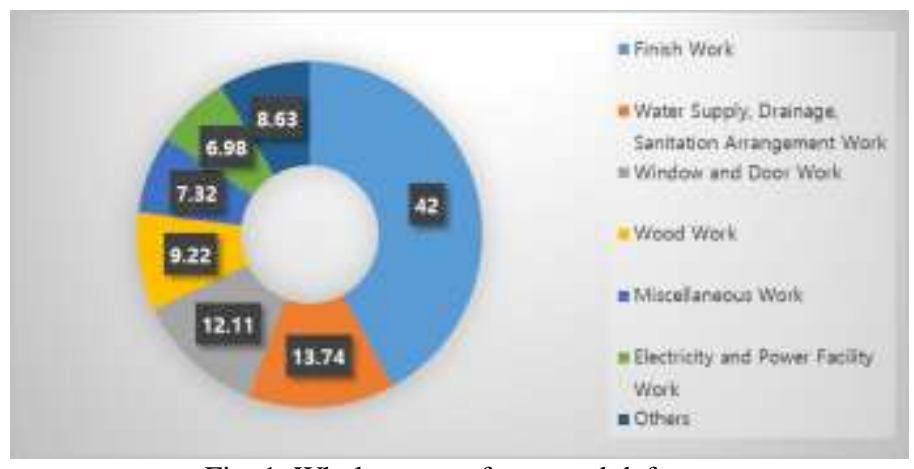

Fig. 1. Whole status of occurred defect

\section{Occurrence of Finish Work Defect}

The status of defect occurring in detailed construction type of finish work is as follows (Figure 2). The 1st place was $31.31 \%$ of total as indoor furniture work and the 2nd place was tile work of $23.03 \%$. The defects occurring in these two detailed construction types exceeded half of finish work defects. Followed by wallpaper work of $17.52 \%$ in the 3 rd place, interior finishing work of $16.93 \%$ in the 4th, and painting work of $9.75 \%$ in the 5th. Besides that, plastering work and insulation work was relatively small.

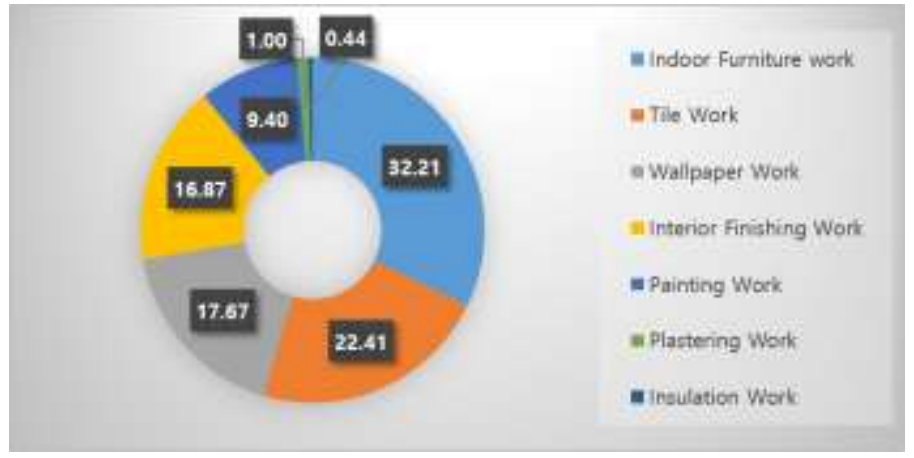

Fig. 2. Status of finish work defect

\section{OCCURRENCE TREND OF FINISH WORK DEFECT}

The number of defect occurrence of finish work surveyed in the previous chapter, occurrence status every year from 1 to 10 years by term of warranty liability, and the accumulated and changing trends of defect occurrence were reviewed. The 7 
detailed construction types of finish work were examined as follows.

\section{A. Plastering Work Defect}

The following graph shows the number of defects occurrence by year and the number of defects occurrence accumulated every year in plastering work (Figure 3 ). The defect occurred in the 1 st year of completion was $72.8 \%$ and the cumulative number occurred in the 2nd year was $88.8 \%$ and in the 3 rd year was $97.8 \%$. $t$ reached $100 \%$ in the 6th year after that, and it is found that the defect did not occur for 4 years afterwards.

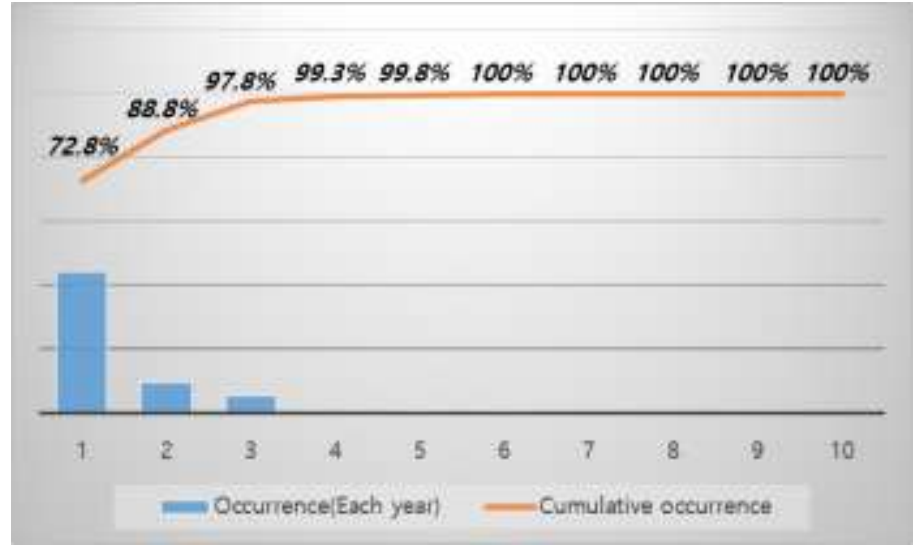

Fig. 3. Occurrence trend of plastering work defect

\section{B. Interior Finishing Work Defect}

The following graph shows the number of defects occurrence by year and the number of defects occurrence accumulated every year in interior finishing work (Figure 4). Like the plastering work, the defect occurrence in the 1st year of completion was $76.7 \%$. It was gradually increasing until the 4th year after that, and there was no further defect occurrence from the 6 th year.



Fig. 4. Occurrence trend of interior finishing work defect

\section{Painting Work Defect}

The following graph shows the number of defects occurrence by year and the number of defects occurrence accumulated every year in painting work (Figure 5). In the case of painting work, the defects that occurred in the 1st year were less than those of plastering work or interior finishing work. However, it was shown similar tendency in that it was gradually decreased after that, and there was no further defect occurrence from the 6th year. Since then, a very small number of defects occurred, only $0.1 \%$.

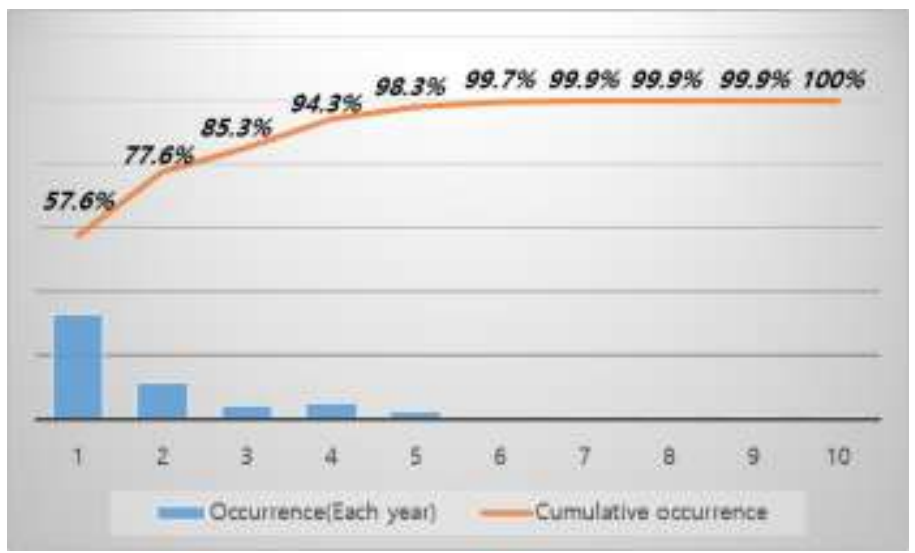

Fig. 5. Occurrence trend of painting work defect

\section{Wallpaper Work Defect}

The following graph shows the number of defects occurrence by year and the number of defects occurrence accumulated every year in wallpaper work (Figure 6). Like the plastering work and the interior finishing work, wallpaper work showed a lot of defects in the 1st year of completion. Generally, there was almost no additional defect occurrence in the 4th year, but it reached $100 \%$ in the 8 th year.

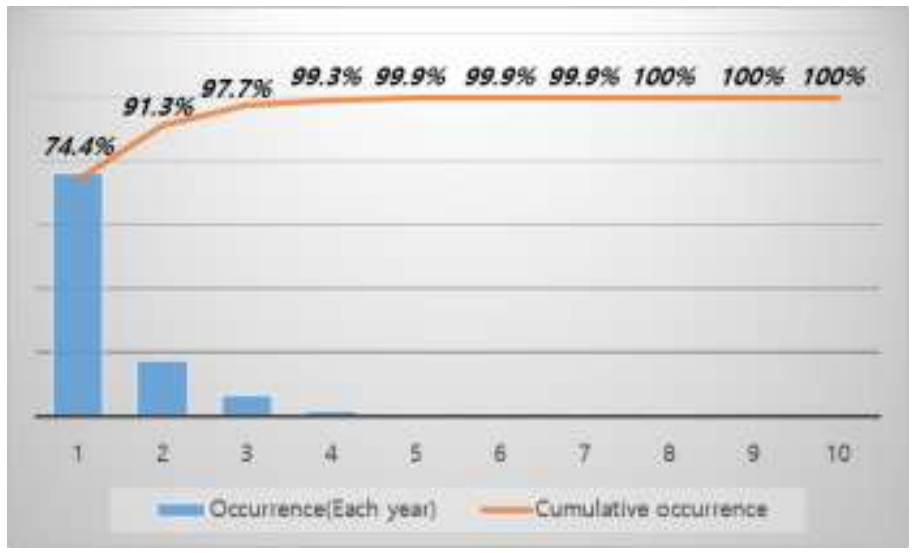

Fig. 6. Occurrence trend of wallpaper work defect

\section{E. Tile Work Defect}

The following graph shows the number of defects occurrence by year and the number of defects occurrence accumulated every year in tile work (Figure 7). In tile work, the tile work showed a lot of defects in the 1st year of completion, and there was minimal additional defect occurrence in the 5 th year. After that, it was shown that there was no additional defect occurrence in the 8th year, just like the wallpaper work. 


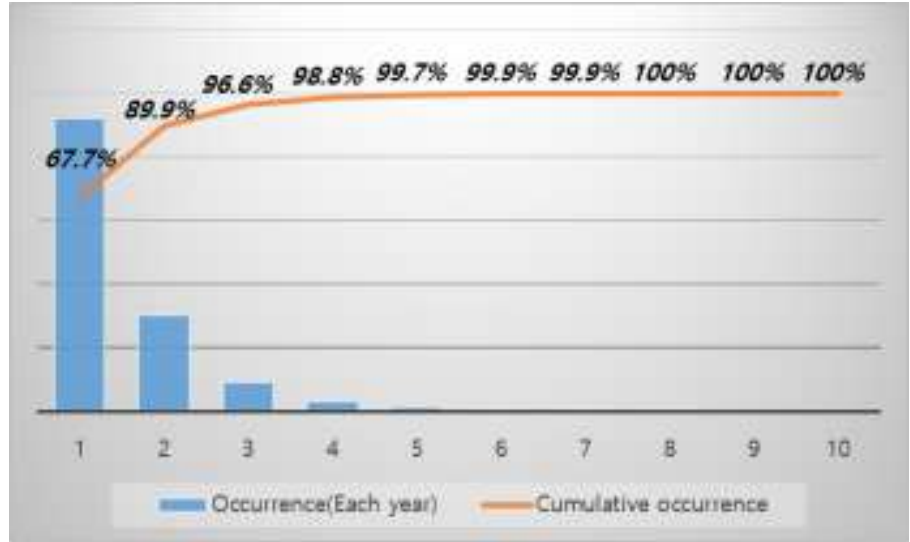

Fig. 7. Occurrence trend of tile work defect

\section{F. Insulation Work Defect}

The following graph shows the number of defects occurrence by year and the number of defects occurrence accumulated every year in insulation work (Figure 8). Insulation work was the least in the 1st year of completion among the seven detailed construction types of finish work. However, it tended to increase rapidly by $89.7 \%$ in the 2 nd year. After that, the defect occurrence gradually decreased, like other construction types, but it reached $100 \%$ in the 10th year.

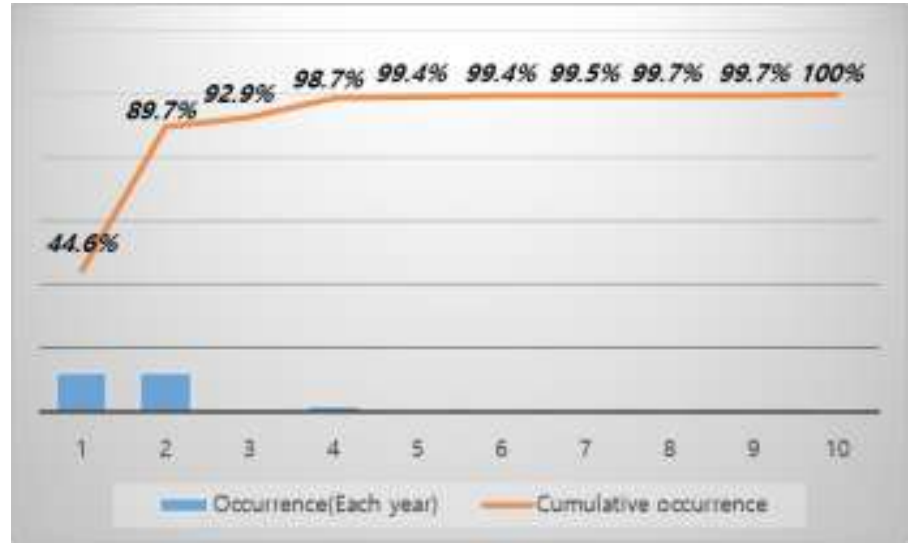

Fig. 8. Occurrence trend of insulation work defect

\section{G. Indoor Furniture Work Defect}

The following graph shows the number of defects occurrence by year and the number of defects occurrence accumulated every year in indoor furniture work (Figure 9). In the case of indoor furniture work, which has the largest number of defects among detailed construction types of finish work, it was similar to that of plastering work and interior finishing work above. The defect occurrence in the 1st year of completion was $74.5 \%$, which increased to $94.4 \%$ in the 2 nd year. It was confirmed that there was no defect occurrence in the 7th year as it exceeded $99 \%$ from the 3rd year.

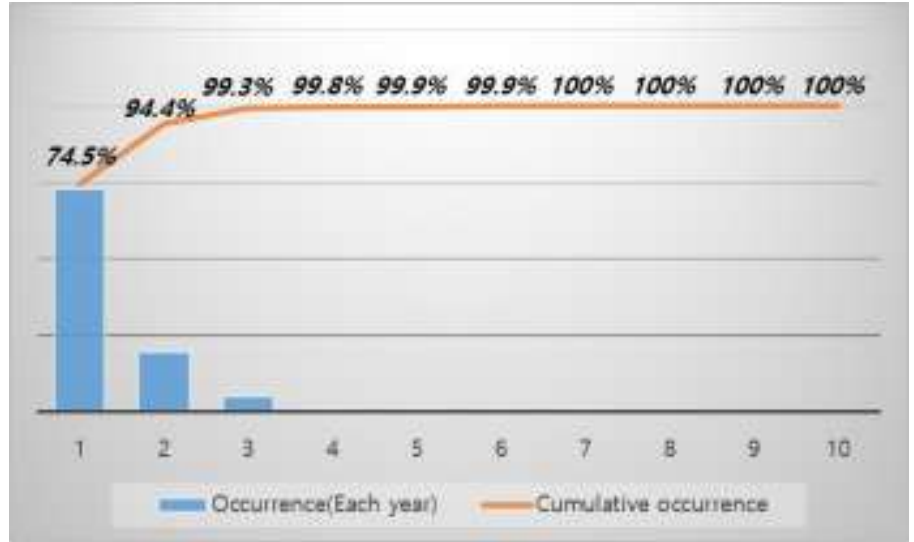

Fig. 9. Occurrence trend of indoor furniture work defect

\section{H. Result and Implication}

The results of analysis on the trend of the cumulative number of defect occurrence in apartment building finish work are as follows by completion year. First, 6 construction types of finish work except for insulation work were found to have more than $50 \%$ defects in the first year of completion. On the other hand, insulation work was relatively low by $44.6 \%$. Second, the defect occurrence in the 1st year of completion was concentrated by more than $70 \%$ in plastering work, interior finishing work, wallpaper work, and indoor furniture work. In addition, it showed $60 \%$ of the tile work and $50 \%$ of painting work. Third, the cumulative number of defect occurrence until the 2nd year of completion showed more than $90 \%$ in interior finishing work, wallpaper work, and indoor furniture work. More than $80 \%$ of defects occurred in plastering work, tile work, and insulation work, and the painting work was the lowest at more than $70 \%$. Third, the cumulative defect occurrence until the 3rd year of completion showed more than $90 \%$ in all of 6 detailed construction works except for the painting work. On the other hand, the painting work showed only $85.3 \%$. It was confirmed that the painting work was more than $90 \%$ in the 4th year.

Examining the overall trends suggests the following points. In all 6 construction types of except for insulation work, defect occurrences were concentrated in the 1 st and 2 nd years, and the defect occurrence of the 1 st year were very high, and decreased sharply from the 2nd year and very low from the 3rd year. However, the tendency was that the difference in defect occurrence in the 1st and 2nd years in interior finishing work was the largest at 4.6 times, while the difference in painting work was relatively small. On the other hand, in the case of insulation work, the defects in the 1 st and 2 nd years were similar level, but the 2nd year was slightly more. However, the tendency of defects to concentrate in the 1st and 2 nd years was not significantly different.

On the other hand, the following points should be supplemented as limitations of this study in future studies. First, the status survey of defect occurrence of this study was limited to the occurrence of defects. In other words, the severity of defect occurrence and the level of damage could be unknown. Since the occurrence of defects is related to defect repair, related information is needed additionally, but it was difficult to grasp it. Second, as a reference standard for establishing the 
term of warranty liability, it is necessary to hear the opinions of related experts such as professional appraisers, lawyers, construction engineers, etc. on the point of time when defect occurrence is ended.

\section{CONCLUSION}

In Korea, disputes and lawsuits over the defect of apartment building are constantly becoming a social problem. In lawsuits over the defect the apartment building, the term of warranty liability, as the period that can demand the defect repair according to defect occurrence, is important because it is the exclusion period of the exercise of rights. In the defect lawsuit, it is very important because the right to request defect repair is judged under term of warranty liability and rejected if the liability period expires. However, at the time of enactment of the relevant law and regulation, it was described without sufficient basis, and subsequent amendments were made arbitrarily without clear basis. Therefore, it is necessary to formulate a basis system promptly through sufficient research and review related to the term of warranty liability.

This study conducted basic research for a reasonable establishment of term of warranty liability for the subject of the finish work defect out of various defects occurring in the apartment building. The finish work is the most in the number of defect occurrence, and it is also important in terms of defects repair costs. For the analysis, we investigated the number of defect occurrence in 177 apartment complexes in Korea, and reviewed the trends of defects by detailed construction type and by year. The expected results are summarized as follows.

First, the total number of occurrences of defects in the apartment complex surveyed was confirmed to be $1,449,745$, and the number one of defect occurrence was finishing work by $42.54 \%$. Through this, it was confirmed that the construction type of most frequent occurrences of defects in apartment housing was finish work. Second, the detailed construction types of finish works are divided into 7 categories. if they are listed the in order from the largest number of occurrences of defects, it showed in order of indoor furniture work, tile work, wallpaper work, interior work, painting work, plastering work, insulation work.

Third, as a result of reviewing defect occurrence and accumulated trends every year from 1 to 10 years on the number of defect occurrence of finishing work by term of warranty liability, it was found that 6 construction types of finishing works except for insulation work had defects of more than $50 \%$ after the first year of completion. Also, in the third year of completion, the accumulated trends of defect occurrence exceeded $90 \%$ in all of 6 detailed construction types of works except for painting work.

The overall tendency of defect occurrence trends showed that defect occurrence in 6 detailed construction type except for insulation work was concentrated in the 1 st to 2 nd year, that is, the number of defect occurrence of the 1st year was very large, started to decrease rapidly from the 2 nd year, and was very small from the 3rd year.

As a follow-up study of this study in the future, we intend to hear the opinions of related experts on the ending point of time of defect occurrence as a reference standard for establishing the term of warranty liability.

\section{ACKNOWLEDGMENT}

This work was supported by the National Research Foundation of Korea (NRF) grant funded by the Korea government (2016R1A2B4012485).

\section{REFERENCES}

[1] J. Park and D. Seo, "Basic Study on Influence Factors for Defect Repairing Cost of Apartment Building in Korea," presented at the 2016 International Conference on Applied Mathematics and Mechanics, Bangkok, Thailand, Oct 29-30, 2016.

[2] J. Park, D. Seo, J. Choi, O. Kim, K. Park, and J. Jo, (February 2012) Analysis on legal issue of lawsuits and subjective judgment on defects in apartment building. Journal of the Korea Institute of Building Construction. 12(1). Pp.42-53. https://doi.org/10.5345/JKIBC.2012.12.1.042

[3] Housing Law

[4] Decree on the Management of Apartment Houses

[5] Apartment House Management Law

[6] Korean Institute of Construction Engineering and Management. A research for judged standard, investigated method and estimated costing of defect in apartment building. Seoul, Korea: Korean Institute of Construction Engineering and Management; 2012. pp. 93-94.

[7] Regulations on the Management of Apartment Buildings



Junmo Park was born in 1980 in Seoul, South Korea. $\mathrm{He}$ currently lives and works for Gyeongsan Engineering in Seoul. He majored in Architectural Engineering at the Chungbuk National University in Korea, graduated in 2006 with a master's degree in 2008, and received his Ph.D in 2012. Since 2005, he has been involved in various research and development projects commissioned by the Korean government and corporations and has lectured at many universities since 2010. Research on the defects of apartment buildings has been carried out with Professor Deokseok Seo, with support from Korean government over 5 projects since 2008. Currently, he is working with Professor Deokseok Seo on the term of warranty liability for apartment housing.

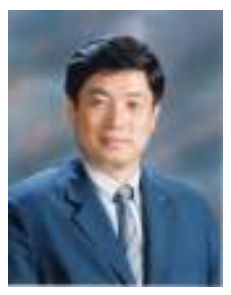

Deokseok Seo was born in Gongju, Korea in 1964. He currently lives in Wonju, Korea and is a professor of the College of Architecture at Halla University. He received bachelor's, master's, and doctoral degrees from Korea University in Korea. He also worked as a researcher at Korea Land \& Housing Corporation, the only professional public company in Korea's apartment houses. He is the first researcher who received a doctorate in research on defects in apartment housing in Korea. Until now, he has been conducting various researches with government support on defects in apartment houses. In 2016, he was also listed in the World Dictionary of Marquis Who's Who in the World. In addition, he received a commendation from the Minister of Education as an excellent researcher. He has done various researches with Dr. Junmo Park, and has written academic papers and thesis. Recently, with the support of the Korea Research Foundation, a specialized research institute under the Ministry of Education, Korea, he is conducting a study on the term of warranty liability in apartment buildings. 